\title{
ANALISIS KESALAHAN PENGGUNAAN TANDA BACA BAHASA TIONGHOA DALAM MENULIS DAN MEMBACA OLEH MAHASISWA KELAS MENENGAH DAN ATAS SASTRA TIONGHOA UNIVERSITAS KRISTEN PETRA 彼得拉基督教大学中文系中高级学生写作与阅读使用标 点符号偏误分析
}

\author{
Filona SagitaWijaya \\ Budi Kurniawan, S.Kom., B.A.,M.Pd.\&Zhu Shuiqing, B.A., M.Pd. \\ Program Studi Sastra Tionghoa Universitas Kristen Petra, \\ Siwalankerto 121-131, Surabaya 60236 \\ E-mail:phi_lo_na@yahoo.com
}

\begin{abstract}
ABSTRAK
Berdasarkan pada penelitian Zeng (2017) telah melakukan penelitian terhadap beberapa hasil penelitian sebelumnya pada tahun 2002 sampai 2016 mengenai analisis kesalahan tanda baca. Dalam penelitian tersebut ditemukan " isi penelitian, cara penelitian dilakukan berulang- ulang", mayoritas data penelitian berupa karangan dari mahasiswa, penelitian yang bersifat eksperimental sangat sedikit (hanya ada satu penelitian). Penulis menggunakan data penelitian dari karangan mahasiswa, proposal mahasiswa dan soal tes kecil, membuat hasil penelitian menjadi lebih objektif, juga menghasilkan penelitian yang bersifat eksperimental.

Pertama, penulis melakukan perhitungna pada analisis kesalahan penggunaan tanda baca, kemudian tahap selanjutnya menggolongkan kesalahan tersebut dan menjelaskan letak kesalahan pada kalimat yang salah. Untuk mengetahui mengenai korelasi pemahaman penggunaan tanda baca yang berkaitan dengan kemampuan membaca dan menulis, penulis menggunakan Pearson Correlation. Hasilnya adalah, kesalahan fungsi dalam penggunaan tanda baca tanda baca koma terhadap kemampuan menulis dan membaca memiliki korelasi yang kuat, sedangkan tanda baca lainnya tidak memiliki korelasi.
\end{abstract}

Kata kunci: tanda baca bahasa Tionghoa, menulis, membaca , error analysis 


\section{摘要}

据曾（2017）对 2002-一2016 年间发表的标点符号教学论文做的统 计, 发现标点符号偏误研究在 “研究内容、研究方法存在重复、单一的倾 向”，语料的选择上以学生作文为主, 实验研究不足（仅有 1 篇）。本文想 了解中文系中高级学生写作时标点符号的标示情况以及学生断句能力与写作 中标点符号偏误是否相关，补充了实验研究上的不足。

笔者首先对语料中的标点偏误情况进行了统计, 然后进一步整理归类, 并尝 试分析了偏误产生的原因。同时, 为了了解书写和阅读断句标点偏误是否相 关，笔者使用了皮尔森相关系数对数据做相关性的计算。结果发现，逗号的 错用偏误占最大比率, 在书写与阅读中也有较强的相关性, 而其它符号则不 存在相关性。

关键词：标点符号、书写、阅读、偏误分析 


\section{PENDAHULUAN}

Mengenai bidang penelitian tanda baca bahasa Tionghoa, sudah cukup banyak sarjana memuat tesis yang berhubungan dengan tanda baca bahasa Tionghoa.Zeng (2017)"isi dari penelitian, cara penelitian yang diulang- ulang, menjadi satu kesatuan” (2007:1003).Penelitian dengan menyebarkan beberapa pertanyaan jumlahnya tidak mencukupi atau jumlahnya sangat sedikit, juga penelitian yang bersifat eksperimental hanya ada satu tesis saja (2007:1006).Giesen (2001) membaca dan menulis adalah kombinasi yang bagus untuk proses belajar mengajar.Zhao (2003) memaparkan bahwa pengajaran membaca dapat memberikan informasi kepada mahasiswa mengenai aturan menulis, sumber untuk menulis, tata cara menulis.Yang dan Wen (2015) memberikan soal kepada 62 mahasiswa tingkat menengah yang berada di Asia Tenggara sebanyak 900 kata terdiri dari 3 paragraf tanpa ada tanda baca untuk mengisi penjedaan dan harus mengisi soal tersebut dengan tanda baca, hasil yang ditemukan adalah mahasiswa asing tingkat menengah memiliki tingkat kemampuan menjeda yang cukup rendah.

Oleh karena itu, penulis menggunakan dua macam data penelitian----berupa karangan mahasiswa dan soal (penelitian bersifat eksperimental) untuk membahas mengenai kemampuan penjedaan dan kemampuan menulis yang berkaitan dengan kesalahan penggunaan tanda baca bahasa Tionghoa pada mahasiswa.

\section{KAJIAN PUSTAKA}

Penulis menggunakan teori tanda baca yang merupakan alat bantu dalam suatu kalimat yang tidak dapat dihilangkan, dapat membantu penulis dan pembaca, sehingga pembaca dapat memahami arti dari penulis. Tanda baca dalam kalimat merupakan tanda jeda yang membantu penjedaan pada kalimat, penekanan kata maupun kalimat. Tanda baca dan tulisan merupakan satu kesatuan sistem. Tanda baca juga dapat mengartikan isi dari kalimat. Tapi ada sebagian orang memandang tanda baca adalah hal yang tidak penting, beberapa orang beranggapan pada saat menulis boleh memakai dan boleh tidak memakai tanda baca (Huang PoRong, 2016, P154).

Menggunakan teori membaca dan menulis, Memahami bacaan merupakan salah satu kebiasaan sehari- hari yang cukup sulit yaitu untuk mendapatkan suatu informasi. Menggunakan bantuan gambar dan tanda baca merupakan cara yang paling dasar untuk mempermudah proses membaca isi dari bacaan dan mengerti penekanan pada tiap kalimat. Dalam suatuj bacaan, bantuan gambar dan tanda sangat berdampak Membaca dapat meningkatkan kemampuan otak dan menambah wawasan pribadi. (berdasarkan D. E. Rumelhart 1984, Chen Hui, 2007, p128129) .

Membaca juga membantu seseorang untuk berlatih menulis sehingga kualitas menulis meningkat. Seperti contohnya berlatih membaca terlebih dahulu pemberitahuan, surat kontrak atau perjanjian, memo, brosur, deskripsi produk, catatan hasil membaca, ringkasan pekerjaan, presentasi, pengalaman, pidato dan sebagainya. Setelah selesai membaca bacaan praktek untuk menulis, namun pada saat menulis hendaknya mengurangi kesamaan (imitasi) dalam bacaan sebelumnya, sehingga memunculkan ide dan gagasan yang lebih bebas dan mandiri sesuai dengan pemikiran penulis. (Lu BiSong, p231). 
Berdasarkan Brown (1994) menyatakan error analysis adalah melakukan pengamatan, analisis, dan mengklasifikasi sehingga memunculkan sistem kesalahan yang dilakukan oleh pembelajar. Error analysis juga menampilkan sumber kesalahan dari pembelajar yaitu: dampak dari native speaker, komunikasi sosial dengan orang sekitar dan psycholinguistic. Berdasarkan Ellis (1986) error analysis merupakan cara analisis yang melibatkan pengumpulan data , mengidentifikasi kesalahan, mendeskripsikan kesalahan, mengelompokan kesalahan sesuai pada hipotesis dan mengevaluasi kesalahan.

Berdasarkan hasil penelitian Zeng (2017 : 1003) dan Liao (2014:34-40), penulis dalam analisis kesalahan tanda baca membagi menjadi jenis kesalahan ke dalam 4 golongan yaitu: kesalahan penggunaan, yaitu menggunakan tanda baca tertentu menggantikan tanda baca yang lain; kesalahan format, yaitu kesalahan karena posisi peletakan yang tidak tepat; kesalahan pengurangan, tidak membubuhkan tanda baca atau kekurangan tanda baca yang seharusnya ada pada kalimat tersebut; kesalahan penambahan, yaitu kelebihan jumlah tanda baca pada suatu kalimat yang seharusnya tidak perlu lagi dibubuhkan.

Berdasarkan Sugiyono (2007),Korelasi Pearson berguna untuk menjelaskan tingkat kekuatan korelasi linier antara dua variabel. Ruang lingkup koefisien korelasi Pearson ini pada angka -1 sampai 1, yang berarti jika hasil menunjukan 1 maka dua variabel tersebut berkorelasi linier positif sempurna, maksudnya adalah jika satu variabelnilainya semakin besar, maka variabel lainnya nilainya juga akan semakin besar.Jika hasilnya -1 artinya dua variabel berkorelasi linier negatif sempurna, maksudnya adalah jika satu variabel nilainya semakin besar, maka variabel yang lain nilainya semakin kecil;Jika hasil menunjukkan angka 0 , artinya tidak ada korelasi apapun pada kedua variabel.

Cohen (1988) menjelaskan bagaimana menjelaskan maksud dari koefisien korelasi Pearson; angka 0,1 sampai 0,3 menunjukkan korelasi lemah, 0,3 sampai 0,5 menunjukan tingkat korelasi menengah, melebihi 0,5 menunjukan adanya korelasi yang kuat. Hasil negatif juga dapat menggunakan penjelasan mengenai tingkat kekuatan korelasi di atas, hanya saja hubungan korelasinya negatif ( jika nilai variabel satu semakin besar,maka variabel lainnya semakin kecil).

\section{METODE PENELITIAN}

Metode penelitian adalah dengan menggunakan metode penelitian kuantitatif. Dengan metode ini dapat mengetahui hasil dalam bentuk angka- angka hasil perhitungan dan menggunakan statistik. Dalam pengumpulan data, penulis menggunakan dua cara, yaitu: dari 195 karangan dan tes. Penulis mengarah kepada mahasiswa angkatan menengah dan atas (tahun 2014 dan tahun 2015) dalam membagikan soal tes, isi dari soal tes tersebut berupa 3 paragraf bacaan tanpa ada tanda baca, 3 paragraf tersebut diambil dari soal- soal cerita HSK4. Melalui cara ini, penulis dapat mengetahui pemahaman mahasiswa terhadap bacaan meskipun tanpa adanya tanda baca. Untuk mengetahui perhitungan korelasi, penulis menggunakan Pearson Correlation. 


\section{ANALISIS}

Penulis menjabarkan dua golongan kesalahan dengan frekuensi kesalahan terbanyak beserta contoh kesalahan yang sering muncul. Berikut adalah tabel frekuensi kesalahan berdasarkan golongan kesalahan dari tiap jenis tanda baca.

Tabel 1 Daftar 13 tanda baca dan penggolongan kesalahan.

\begin{tabular}{|l|c|l|c|c|}
\hline Tanda Baca & $\begin{array}{l}\text { Kesalahan } \\
\text { Fungsi }\end{array}$ & $\begin{array}{l}\text { Kesalahan } \\
\text { Posisi }\end{array}$ & Pengurangan & Penambahan \\
\hline Titik & 24 & 6 & 4 & 23 \\
\hline Koma & 125 & 0 & 13 & 13 \\
\hline Dunhao & 11 & 0 & 3 & 7 \\
\hline Petik tunggal & 0 & 0 & 0 & 0 \\
\hline Petik dua & 1 & 0 & 11 & 0 \\
\hline Titik dua & 1 & 0 & 13 & 0 \\
\hline Titik koma & 6 & 0 & 0 & 0 \\
\hline Guillemets & 1 & 0 & 0 & 0 \\
\hline Tanda pisah & 0 & 0 & 0 & 6 \\
\hline Kurung & 0 & 0 & & \\
\hline
\end{tabular}

\subsubsection{Kesalahan Fungsi}

\section{Tanda Titik}

Dari tabel dapat mengetahui, kesalahan tanda baca pada tanda titik ada 24 kesalahan, penulis menggolongkan kesalahan menjadi 3 macam, yaitu :

(1) Menggunakan tanda titik dalam kalimat tanya.

Contoh :

（1）她也喜欢游泳，我们也常常一起去游泳，有一次，我们因为没有 钱，所以我们想，怎么可以游泳但是不付钱呢 $\mathrm{a}_{\text {。 }}$

(2) 然后我想, 要上什么系呢 $a_{\text {。 }}$

Pada posisi huruf a di atas seharusnya digunakan tanda tanya. Kalimat tersebut adalah kalimat tanya. Pada akhir kalimat tanya seharusnya diberi tanda tanya. Kalimat tanya pada umumnya digunakan untuk mengajukan pertanyaan, dan 
mengandung nada bertanya. Tanda baca titik digunakan pada akhir kalimat berita. Mahasiswa di sini menggunakan tanda titik, menandakan ketidakpahaman atas penggunaan tanda tanya dan titik.

(2) Pemakaian tanda koma menjadi tanda titik.

Contoh:

(1) 在我家乡, 我有一个最好的同屋 $\mathrm{a}$ 。她叫美燕, 是我妹妹。

(2) 在外南梦除了 Sego Tempong 以外, 当地还有很多特色美食, 例如 : Sego Cawuk, Rujak Soto, Soto Using, Pecel Rawon 和 Ayam Pedas a。都很好吃。 Pada posisi huruf a di atas, seharusnya diletakkan tanda koma, dan subjek 她 dihilangkan. Dua kalimat tersebut adalah dua kalimat tunggal yang berhubungan. Di dalam bahasa Tionghoa, kedua kalimat ini dapat digabungkan menjadi kalimat majemuk sederhana, sehingga kalimat menjadi lebih ringkas, dan hubungan antara kedua anak kalimat lebih erat. Mahasiswa tidak mengerti tentang kalimat majemuk dan tunggal, sehingga pengungkapan kalimat menjadi monoton. Pada posisi $b$, seharusnya digunakan tanda koma. “都很好吃” di sini adalah predikat dari masakan-masakan yang disebutkan di depan kalimat, sehingga tidak seharusnya dipisahkan dengan tanda titik.

(3) Kesalahan titik koma menjadi tanda titik.

Contoh :

(1) 原因是第一, 中文是世界上说得第二多的语言 $\mathrm{a}$ 。第二, 父母让我 学习中文 $\mathrm{a}$ 。第三, 我跟家人喜欢去中国旅行。

Kalimat di atas merupakan kalimat majemuk kompleks. Posisi huruf a dalam kalimat merupakan jeda antara anak kalimat dengan relasi binglie (juktaposisi). Tanda titik koma menyatakan jeda pada relasi binglie di dalam kalimat majemuk, serta jeda dalam anak kalimat tingkat pertama pada relasi non binglie pada kalimat majemuk kompleks. Kesalahan ini muncul karena tidak mengerti hubungan antara anak kalimat.

\section{Tanda Koma}

Dari tabel 1 dapat diketahui bahwa kesalahan tanda baca koma pada golongan ini adalah yang paling banyak jumlahnya yaitu 125 kesalahan. Penulis menjabarkan kesalahan pada tanda koma sebanyak tiga macam :

(1) Dunhao menjadi tanda koma.

Contoh :

(1) 比如说：边学习 $a$, 吃饭 $b$, 睡觉 $c$, 边听音乐。

(2) 除了喜欢韩国电影, 她也喜欢看西方电影, 比如动画片 $\mathrm{a}$, 动作片 和恐怖电影。

Pada huruf a,b,c terdapat kesalahan tanda baca yang sama, yaitu menggunakan 
tanda koma yang seharusnya ditulis dunhao. “学习” “吃饭” “睡觉” adalah kata dengan struktur binglie, sehingga seharusnya mengggunakan dunhao. Dunhao menyatakan jeda di dalam kata-kata dengan struktur binglie di dalam kalimat.

(2) Menggunakan koma pada kalimat tanya.

Contoh :

（1）然后妈妈就骂我, 说：“为什么你喜欢一直抱怨 $a$, 别人可以解决 那个问题, 那为什么你不会呢? ”

(2) 要去旅行的时候, 我们需要规划要去哪里 $\mathrm{a}$, 去国内还是国外 $\mathrm{a}$, 跟 谁去?

Kalimat di atas merupakan kalimat tanya, pada huruf a di atas seharusnya menggunakan tanda baca tanda tanya, meskipun tidak mengharuskan jawaban, tapi kalimat tersebut merupakan bentuk kalimat tanya. Tanda tanya menyatakan jeda pada akhir kalimat tanya. Kata “为什么” dalam kalimat merupakan sebuah kata tanya, untuk menyatakan nada bertanya.

(3) Kesalahan dalam penulisan angka desimal.

Contoh :

(1) $0 \mathrm{a}, 9 \%$ 的含糖量的饮料。

Pada kalimat di atas huruf a menandakan kesalahan penggunaan tanda baca, seharusnya menggunakan tanda baca titik untuk menulis angka desimal.Kesalahan ini disebabkan karena dalam bahasa Indonesia, untuk menyatakan desimal digunakan tanda koma.

\subsubsection{Kesalahan Posisi}

1. Tanda Titik

Berdasarkan tabel 1 dapat diketahui kesalahan pada tanda baca titik ada 6 kesalahan, semuanya memiliki bentuk kesalahan yang sama. Di bawah ini merupakan perwakilan kesalahan, yaitu:

(1) Kesalahan penulisan letak pada tanda petik dua dan tanda titik.

Contoh :

(1) 我一开始都不知道那首歌是他的, 我就问我父亲那首歌是谁唱的, 父亲 回答说：“周杰伦” $a$ 。

(2) 我紧张地说:“嗯嗯, 我的心也很好” a。

(3) 她微笑看着我害羞的样子说:”上课吧“ $a$ 。

Pada posisi a terjadi kesalahan posisi tanda baca. Dalam aturan penulisan tanda baca, pada akhir kutipan yang berupa ucapan lengkap yang bisa berdiri sendiri seharusnya diberikan tanda akhir kalimat di dalam tanda petik; tetapi jika kutipan adalah elemen penyusun kata-kata penulis, tanda akhir kalimat harus diletakkan di luar tanda petik. Dalam contoh di atas, kutipan adalah kutipan lengkap, sehingga 
pada posisi a seharusnya tanda titik diletakkan di dalam tanda petik.

\subsubsection{Pengurangan .}

\section{Tanda Koma}

Berdasarkan tabel 1 dapat diketahui, kesalahan pada tanda baca koma ada 13 kesalahan, di bawah ini merupakan salah satu contoh, yaitu:

Contoh :

(1) 我有三个兄弟姐妹 a 我是第二个孩子。

(2) 从那天起, 我就开始搜索他, 在不知不觉中九年过去了 $\mathrm{a}$ 我一直 喜欢著他。

（3）他们从来没说要我做这个那个却让我顺利地成长并选自己的职业，走自 己的路。

Pada kalimat di atas, pada posisi huruf a tidak ada tanda koma. Kalimat tersebut adalah kalimat majemuk sederhana. Jeda di dalam kalimat harus menggunakan koma. Jika tidak ada tanda koma pada kalimat, maka pembaca tidak akan mengerti di mana letak penjedaan kalimat tersebut.

\section{Titik Dua}

Pada tabel di atas dapat diketahui keslaahn pada tanda baca titik dua ada 13 kesalahan, salah satu contohnya yaitu:

Contoh:

(1) 我对她说 a “hey 不要哭啦? 怎么回事? 告诉我吧！”

（2）购物网站也越来越多，比如 a Tokopedia、Elevenia、OLX、Shopee、 Zalora 等。

Pada kalimat diatas, huruf a menunjukan letak kesalahan, yaitu tidak adanya tanda titik dua.Tanda baca titik dua digunakan untuk kalimat langsung, biasanya digunakan setelah kata ("berkata" "contoh" "mengungkapkan" dan lain sebagainya). Kalimat di atas merupakan kalimat langsung, oleh karena itu perlu dibubuhkan tanda titik dua kemudian juga perlu ditambah dengan tanda baca petik dua.

\subsubsection{Penambahan}

\section{Tanda Titik}

Pada tabel 1 dapat mengetahui, kesalahan tanda baca titik ada 23 kesalahan. Seluruh kesalahan ini muncul pada kalimat langsung yang mana mahasiswa membubuhkan tanda baca titik pada setiap akhir kalimat langsung. 


\section{Contoh :}

（1）我对她说：“喂, 你好! 我是爱纶。我要问, 中文系是什么样的? 我想要 在那儿学习中文，教材是什么样的? 中文很难吗?”a。

（2）秘书回答：“不难啊！因为从基础开始, 所以你放心吧, 不要怕在 中文系学习! ” $a$

(3) 我说:" 三叶, 你好?, 你的学习怎样? “a。

Pada kalimat langsung, kutipan merupakan ucapan yang lengkap. Tanda baca harus diletakkan di dalam tanda petik. Di belakang tanda petik tidak perlu ditambahkan tanda baca lain. Pada kalimat di atas, hururf a menunjukan letak kesalahan pada kalimat, yaitu kelebihan penambahan tanda titik.

\section{Tanda Koma}

Pada tabel 1 dapat mengetahui, kesalahan tanda baca koma ada 13 kesalahan. Adanya tanda koma yang terletak di depan kata bantu keterangan. Contoh :

(1) 我对她说: “hey 不要哭啦? a, 怎么回事? a, 告诉我吧！”。”

(2) 我要认识中文系的学生们, 比如是同班, 学长学姐 $a$, 和老师们。

Pada kalimat di atas, huruf a merupakan letak kesalahan dalam pemberian tanda baca. Tanda baca koma berguna sebagai penjeda bagi kalimat majemuk sederhana.

Tabel 2 Hasil Korelasi Membaca dan Menulis

\begin{tabular}{|l|c|c|c|c|}
\hline Tanda & $\begin{array}{l}\text { Kesalahan } \\
\text { Fungsi }\end{array}$ & $\begin{array}{l}\text { Kesalahan } \\
\text { Posisi }\end{array}$ & Pengurangan & Penambahan \\
\hline Titik & 0,17701 & 0 & $-0,1144$ & $-0,0989$ \\
\hline Koma & 0,69251 & 0 & $-0,1145$ & $-0,035$ \\
\hline Dunhao & 0 & 0 & 0,26057 & 0 \\
\hline $\begin{array}{l}\text { Tanda } \\
\text { Tanya }\end{array}$ & 0,45883 & 0 & $-0,107$ & 0 \\
\hline $\begin{array}{l}\text { Tanda } \\
\text { Seru }\end{array}$ & 0 & 0 & $-0,1403$ & 0 \\
\hline Elipsis & 0 & 0 & 0 & 0 \\
\hline $\begin{array}{l}\text { Petik } \\
\text { Tunggal }\end{array}$ & 0 & 0 & 0 & 0 \\
\hline
\end{tabular}


Wijaya : Analisis Kesalahan Penggunaan Tanda Baca Bahasa Tionghoa Dalam Menulis Dan Membaca Oleh Mahasiswa Kelas Menengah Dan Atas Sastra Tionghoa Universitas Kristen Petra

\begin{tabular}{|l|c|c|c|c|}
\hline Petik Dua & 0 & 0 & $-0,0724$ & 0 \\
\hline $\begin{array}{l}\text { Tanda } \\
\text { Pisah }\end{array}$ & 0 & 0 & 0 & 0 \\
\hline Titik Dua & 0 & 0 & 0,01159 & 0 \\
\hline Titik Koma & 0 & 0 & 0 & 0 \\
\hline Guillemets & 0 & 0 & 0 & 0 \\
\hline Kurung & 0 & 0 & 0 & 0 \\
\hline
\end{tabular}

Menggunakan Pearson Correlation untuk mengetahui garis korelasi antara dua variabel yang berbeda, yaitu kesalahan pada membaca dan kesalahan pada menulis. Hasilnya yaitu :

(1) Kesalahan Fungsi

Pertama, hasil koefisien korelasi tanda baca koma adalah 0,69251.Oleh karena itu dapat dikatakan korelasinya kuat ; kedua, hasil koefisien korelasi tanda tanya adalah 0,45883,dapat dikatakan terdapat korelasi namun tidak terlalu kuat ; ketiga, hasil koefisien korelasi tanda baca titik adalah 0,17701, korelasi terbilang lebih rendah dari tanda koma dan tanda tanya. Untuk tanda baca yang lain hasilnya 0 , jadi tidak ada korelasi apapun. Tanda baca koma merupakan tanda baca umum untuk penjedaan, sehingga mahasiswa dengan bebas menggunakan tanda baca koma dalam kondisi apapun. Kesalahan penggunaan tanda baca koma pada karangan mahasiswa jumlahnya lebih banyak dibanding dengan jumlah penggunaan pada soal tes. Pengajar seharusnya lebih memperhatikan mahasiswa dalam menggunakan tanda baca dengan lebih banyak menjelaskan mengenai berbagai macam jenis tanda baca, serta perbandingan antara tanda koma dengan tanda baca yang lain. Dengan begitu, pemahamanmahasiswa dalam menggunakan tanda baca dapat meningkat..

\section{(2) Kesalahan Format}

Hasil kesalahan formattanda baca tidak ada hubungan korelasi, seluruh hasilnya berupa 0 . Ini karena jumlah kesalahan format yang terjadi sangat sedikit, sehingga korelasinya pun tidak ada.

(3) Kesalahan Pengurangan

Hasil dari koefisien korelasi menunjukkan, pada kesalahan pengurangan tanda baca, penjedaan dan menulis hasil korelasinya sangat lemah. Ini menunjukkan kesalahan pengurangan dalam menjeda bacaan serta menulismuncul karena kecerobohan siswa.

(4) Kesalahan Penambahan

Pada kesalahan ini tidak muncul hasil korelasi yang signifikan. Sama dengan kesalahan pengurangan, munculnya kesalahan penambahan juga karena kecerobohan siswa.

Berdasarkan perhitungan korelasi Pearson, tanda baca koma memiliki hasil korelasi yang paling signifikan dibanding dengan tanda baca lain.Oleh karena itu, 
penggunaan tanda baca koma perlu mendapat perhatian dalam pembelajaran, agar kesalahan penggunaannya dapat dikurangai.

\section{KESIMPULAN}

Kesimpulan yang dapat diambil adalah bahwa frekuensi penggunaan tanda baca koma banyak, juga jumlah kesalahan pada tanda baca koma memiliki angka terbanyak dibanding tanda baca lainnya. Kesalahan pada tanda baca koma berada pada golongan kesalahan fungsi penggunaan tanda baca. Oleh karena tanda baca koma merupakan alat bantu menjeda pada kalimat yang sangat standart dibanding tanda baca lainnya, mahasiswa sering mengaplikasikan tanda baca koma ini pada kalimat. Mahasiswa sering mengganti tanda baca yang seharusnya dipakai menjadi tanda baca koma sebagai penjeda. Kesalahan tanda baca yang erat kaitannya dengan menulis dan membaca juga tanda baca koma. Berdasarkan perhitungan Pearson Correlation, kesalahan pada tanda baca koma digolongan kesalahan fungsi penggunaan tanda baca menghasilkan angka yang berarti berkorelasi kuat dibanding kesalahan lainnya.

\section{DAFTAR PUSTAKA}

Brown, H. Douglas (1994). Principles of Language Learning and Teaching. Prentice Hall. ChenHui (2008). Dui Wai Han Yu Zi Ci Yu Yue Du Xue Xi Yan Jiu. Bei Jing Zhong Ke Yin Shua You Xian Gong Si.

ChenHui(2007). Dui Wai Han Yu Jiao Xue Ke Cheng Yan Jiu. Bei Jing : Bei Jing Zhong Ke Yin Shua You Xian Gong Si.

Cohen, J. (1988). Statistical power analysis for the behavioral sciences (2nd ed.). Hillsdale, NJ: Lawrence Erlbaum Associates.

Ellis, Rod (1986). Understanding Second Language Acquisition. New York:

Oxford University Press.

Giesen, Leslie, "Activities for Integrating Reading and Writing in the Language Classroom" (2001). MATESOL Collection. 456.

$\mathrm{Hu}$ Yu Shu (1993). Xian Dai Han Yu. Hongkong: Joint Publishing.

LuBiSong (2007). Han Yu He Han Yu Zuo Wei Di Er Yu Yan Jiao Xue.Bei Jing: Bei Jing Da Xue Chu Ban She.

Sugiyono. 2007. Metode Penelitian Kuantitatif Kualitatif dan R\&D. Bandung: Alfabeta.

Wang Li Jia (2000). X ian Dai Han Yu. Bei Jing: Shang Wu Yin Shu Guan.

WangZiQiang(1984). Yong Ci.Zao Ju.Biao Dian. Shang Hai : Shu Hai Chu Ban She.

YangWanBing (2015) . Zhong Ji Shui Ping Dong Nan Ya Liu Xue Sheng Han Yu Ju Du Yi Shi Yu Biao Dian Fu Hao Shi Yong De Shi Yan Yan Jiu. Yu Yan Jiao Xue Yu Yan Jiu.

ZengLiJuan (2017) . Mian Xiang Han Yu Guo Ji De Biao Dian Fu Hao Yan Jiu Shu Ping. Chang Sha: Hu Nan Shi Fan Da Xue Guo Ji Han Yu Wen Hua Xue Yuan. 
Wijaya : Analisis Kesalahan Penggunaan Tanda Baca Bahasa Tionghoa Dalam Menulis Dan Membaca Oleh Mahasiswa Kelas Menengah Dan Atas Sastra Tionghoa Universitas Kristen Petra

Zhao ZhenMing (2003) . Xie Zuo Jiao Xue Yu Yue Du Jiao Xue De Xie Tong Guan Xi. 《Yu Wen Jiao Xue Yu Yan Jiu: Jiao Yan Tian Di》terbit 04.

ZhaoJinMing(2008). Dui Wai Han Yu Jiao Xue Gai Lun. Bei Jing : Shang Wu Yin Shu Guan. 